\title{
A RUSKIN LETTER
}

\author{
By C. Rexford Davis
}

Of letters by Fobn Ruskin to bis intimate friend Artbur Severn only four bave ever been printed in collections. This fact gives added interest to the one which is bere publisbed for the first time. Professor Davis, of the Class of 1928, bas been a member of the Department of English ever since bis graduation, and bas taken particular interest in English literature of the nineteentb century.

FEW months ago the Library received as a gift from the Rev. John H. S. Putnam, of the Class of I9I3, a letter 1 by John Ruskin with its enclosing (?) envelope. The
envelope is postmarked at Abingdon November 5, I875, and is addressed to Arthur Severn Esq., Herne Hill, SE, London. The letter follows:

My dear Arthur-

Tuesday

I've got into a bad habit of being Grammatical lately-it's very inconvenient-I said we should be "at Kenilworth"-instead of-"at-Amy Robsart"-one could be at Amy's feet-I suppose-if one had the chancenot that I ever used to go wild for the queene of tragedy, in my submissivest days-it is so much easier to cry than to laugh, with a grace. Well-it's Drury lane - at any rate - to Thursday evening.

Ever faithfully yours,

J. Ruskin

In this letter and its envelope we possess interesting evidence of the occasional carelessness, or ignorance, of the dealer in collectors' items, for the two do not belong together. A study of the letter reveals this fact clearly, at the same time casting light upon Ruskin's relationship with his close friend Arthur Severn.

Arthur Severn, to whom the letter is addressed, was the son of the artist Joseph Severn, who while British consul at Rome was a close friend of Keats. In I 840 Ruskin, then twenty-one years of age, had met the elder Severn when on a tour of the art galleries of Italy in company with his parents and he never forgot Severn's gracious hospitality and many courtesies. At that time Arthur was a mere lad, but when in 1867 he visited Denmark Hill, where Ruskin's mother was living her last years, Ruskin was delighted with the young man, who possessed un- 
Tuaren

Ul dear fochur -

In yoh mits a bael holit

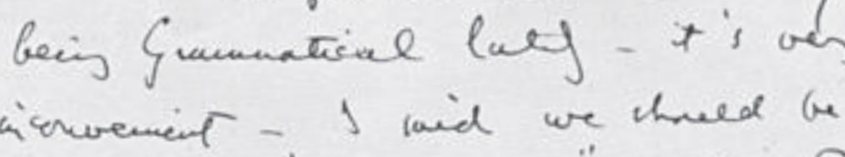

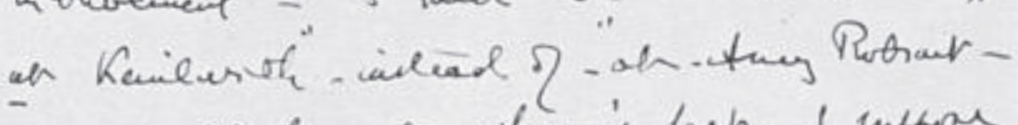

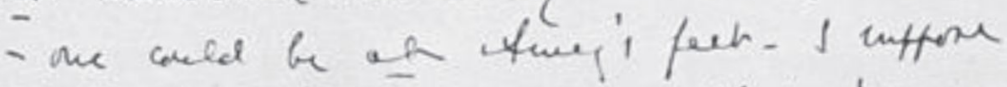
- If me hal th chance - we that Jeven ukel to go will in th quere?

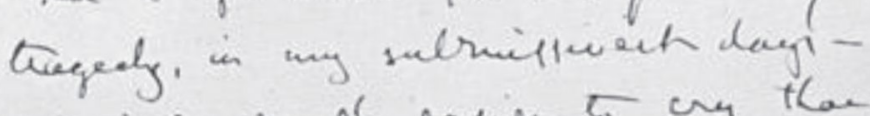

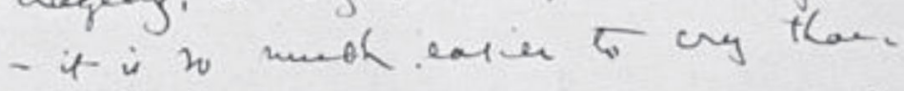
\& band, with a ynare.

woll. it Daury lave. of vey nate-A Theusdy wering.

in fuctsfor Jom.

John Ruskin to Arthur Severn

"sing 
deniable artistic gifts, and employed him with increasing frequency in making sketches and drawings. The friendship of master and neophyte-for so Arthur considered himself-grew ever stronger. But there was an even better reason for Arthur's visits to Denmark Hill, for there he had met Miss Joanna Ruskin Agnew, Ruskin's Scotch cousin. In I 864 Ruskin had brought her to visit his mother for a week. But the visit of seven days lengthened into a stay of seven years, because Ruskin's mother, irritable and hard to get along with, insisted that no one understood her as Joan did, and would not hear of her departure. When Joan finally left, it was to be married to Arthur Severn, in April of I $87 \mathrm{I}$. Old Mrs. Ruskin no longer needed Joan's companionship; scarcely conscious or in her right mind, she hovered between life and death until December 5 of that year.

The intimacy between Ruskin and the Severns helps us to determine the date of the letter to Arthur. In the Library Edition of Ruskin's works we have only four letters addressed to Arthur Severn. (I have been unable to discover any such in any other collection of Ruskin's letters.) The last of these four letters-dated July I 5, I88 I-has no salutation. It is significant that the other three letters address Arthur as 'My dearest Arfie' (Feb. 27, 1873), 'My dear Arfie' (Sept. 17, 1875), 'Dearest Arfie' (Aug. 29, I880). "Arfie" was the pet name which Ruskin used for Arthur after the marriage. Since by the year 1875, the date of the envelope, the intimacy was fully developed, we should certainly not expect a letter from Ruskin to bear the salutation 'My dear Arthur.' It is scarcely conceivable, indeed, that he would have used the salutation ' $\mathrm{My}$ dear Arthur' after April I87I, still less in November I875-strong, though not conclusive evidence that the envelope of 1875 does not belong with the letter.

The subject of the letter clearly is an appointment for the thea tre. The mistake to which Ruskin refers was a wholly natural one. The play Amy Robsart was a drama in four acts by A. Holliday, founded on Scott's novel Kenilworth. The scene was, of course, Kenilworth Castle, so that Ruskin had been indeed 'grammatical' when he said 'we should be "at Kenilworth." But the significant fact is that there was no performance of Amy Robsart at the Drury Lane Theatre-or, for that matter, anywhere else-in November I875. The first performance of 
the play was acted at the Drury Lane Theatre on Saturday, September 24, I870. It had a successful run, closing on Saturday, December 17, I870, to permit the presentation of a special Christmas program, after 73 successive performances. It began a second run on Monday, February 27, I871, and finally was taken off the boards on Saturday, April I, I87 I. Later revivals of the play for short runs occurred as follows: at the Drury Lane Theatre, beginning in January, 1874 ; at the Drury Lane Theatre, beginning in October, 1877 ; at the Adelphi Theatre, beginning in June, I879; and at Sadler's Wells, beginning in December, I 88I. No other presentation is on record. From this evidence it is firmly established that the envelope does not belong with the letter.

When was the letter written? The relationship between Arthur Severn and Ruskin strongly suggests that it cannot be dated as late as 1874 . It must therefore have been written either between September 27, 1870 (the first Tuesday after the opening performance), and December I2, I 870 (the last Tuesday before the first closing), or between February 28, I 87 I (the first Tuesday after the second opening), and March 28, I87 I (the last Tuesday before the second closing). Any more exact dating cannot be satisfactorily established on the basis of the available evidence. It may be noted, however, that Ruskin was an inveterate theatre-goer, attending whenever possible, even to the neglect of what he considered his duties. It is therefore extremely unlikely that he would have waited until I87 I to attend Amy Robsart. We may safely assume that the letter was written between September 27 and December I 2 of 1870 . When we consider further that Ruskin was extremely fond of Scott and that plays at that time seldom had as long a run as the first run of $A m y$ Robsart, we may well believe that he took an early opportunity to attend. It is probable that the letter was written in September or October of 1870 . This is as much as we can do at the present time to date it. It may be that the letter which originally was sealed in the envelope will turn up, and with it the envelope which belongs to the letter we have been examining. If so, we shall then be able to date the latter exactly. 